\title{
EVALUATION OF THE TECHNOLOGICAL QUALITY OF GRAIN AND FLOUR OF TWO SPELT WHEAT (TRITICUM AESTIVUM SSP. SPELTA L.) CULTIVARS GROWN UNDER DIFFERENT CONDITIONS OF CROP PROTECTION AND SEEDING RATE
}

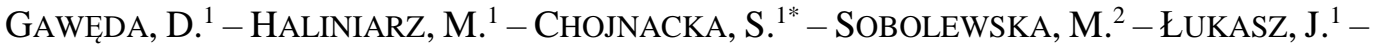 \\ HURY, G. ${ }^{2}$ - WESOlOWSKA-TROJANOWSKA, M. ${ }^{3}$ \\ ${ }^{I}$ Department of Herbology and Plant Cultivation Techniques, University of Life Sciences in \\ Lublin, 20-950 Lublin, Poland \\ ${ }^{2}$ Department of Agronomy, West Pomeranian University of Technology in Szczecin \\ 71-459 Szczecin, Poland \\ ${ }^{3}$ Department of Biotechnology, Microbiology and Food Nutrition, University of Life Sciences in \\ Lublin, 20-950 Lublin, Poland \\ *Corresponding author \\ e-mail: schojnacka2@gmail.com \\ (Received $9^{\text {th }}$ Jan 2019; accepted $28^{\text {th }}$ Feb 2019)
}

\begin{abstract}
A field study was conducted during the period 2014-2015 at the Czesławice Experimental Farm in Poland. The aim of this study was to determine the technological characteristics of the grain and flour of winter spelt (Triticum aestivum ssp. spelta) two cultivars ('Rokosz' and 'Schwabenspelz') depending on the density of sowing and crop protection methods. The present study showed that crop protection method and seeding rate did not cause most of the quality characteristics of spelt grain and flour to significantly vary. Both the Polish cultivar 'Rokosz' and the German cultivar 'Schwabenspelz' exhibited similar technological quality of grain and flour under organic farming and chemical crop protection conditions. Therefore, both these cultivars can be recommended for cultivation in organic farms. In 'Rokosz', gluten content, Zeleny sedimentation value, and dough development time increased with increasing protein content, whereas gluten weakening decreased, which is the evidence of a higher quality and baking value of this cultivar relative to 'Schwabenspelz'.
\end{abstract}

Keywords: chemical and pro-ecological protection, sowing rate, farinographic features of flour and dough, quality characteristic of grain, winter spelt cultivar

\section{Introduction}

Spelt wheat (Triticum aestivum ssp. spelta) is one of the oldest wheat subspecies (Szumiło and Rachoń, 2015; Stankowski et al., 2016). Numerous archaeological studies show that it originated from the south-western region of Asia (Krawczyk et al., 2008a; Cacak-Pietrzak et al., 2013), but for a long time it has also been grown in Germany, Switzerland, Belgium, Slovakia, the Czech Republic, Italy, Canada, and the USA (Stankowski et al., 2016). Despite the fact that in large-area cultivation it was replaced by the more threshable and productive common wheat (Podolska et al., 2015; Ugrenović et al., 2018), in recent years the beneficial properties of spelt wheat are being discovered anew. This species owes its renewal predominantly to the growing interest in healthy food and organic farms, where spelt is frequently grown due to its high resistance to adverse environmental conditions, diseases, and pests (Kraska et al., 2013; Callejo et al., 2015; Rachoń et al., 2016; Babenko et al., 2018). Moreover, spelt wheat has a long stem and high tillering ability, and hence it exhibits high weed competitiveness (Rachoń et al., 2016). 
According to 2015 data of the Central Statistical Office, in 2015 nearly 270,000 organic farms with an area of more than 11.1 million hectares were recorded in the EU, which accounts for $6.2 \%$ of the total agricultural land area. In the same year, in Poland there were more than 22,000 organic farms with an area of over 580,000 ha, which accounts for 3.8\% of Poland's total agricultural land area (Statistical Yearbook of Agriculture, 2017).

Consumers seeking food of high nutritional value readily choose spelt products, driven by the nutrient richness and health-enhancing properties of spelt wheat (Callejo et al., 2015; Rachoń et al., 2016; Boukid et al., 2018). Spelt grain is most often used to make whole grain food products, e.g. bakery products, pasta, muesli, or cereals (Benincasa et al., 2015; Boukid et al., 2018). Compared to common wheat, eating spelt grain products prevents hypertension, reduces blood cholesterol level, improves the functioning of the digestive system, and aids the nervous system (Solarska et al., 2012; Spychaj-Fabisiak et al., 2014). The most important technological parameters of spelt flour are similar to those of common wheat flour, but the observed differences weigh in favour of spelt flour (Rachon et al., 2011). It contains more protein, including gluten, vitamins A, E, D, B, PP, micro- and macronutrients, fats, and necessary amino acids (Lacko-Bartošová, 2010; Escarnot et al., 2012; Biel et al., 2016a; Zorovski et al., 2018). Its total protein content ranges from 13 to 19\% DM (Biel et al., 2016c). Gluten obtained from spelt flour added to low protein flour increases the amount of protein and improves the technological properties of such flour (Rachon et al., 2011). Due to the poorer milling properties of spelt grain, lower milling yields are obtained from it compared to common wheat grain (Krawczyk et al., 2008b). Flour extracted from spelt grain is a good raw material to produce high quality bakery products (Pruska-Kędzior et al., 2008). Spelt bread loaves bake well, do not crumble when cut, and smells and tastes slightly of walnut (Callejo et al., 2015). It should be noted that spelt dough can have a looser texture than dough made of common wheat flour (Biel et al., 2016b). This is due to the spelt gluten which is characterized by high weakening, while the dough by excessive extensibility (Krawczyk et al., 2008a). The rheological properties of spelt flour and dough primarily depend on the gluten content and a proper gliadin-toglutenin ratio (Callejo et al., 2015; Biel et al., 2016b).

The study hypothesized that spelt grain and flour obtained from organically grown spelt (no crop protection, mechanical weed control) would have similar or more favourable technological properties than grain and flour obtained from a chemically protected crop (herbicide protection, complete chemical crop protection). An assumption was also made that an increased seeding rate $\left(500\right.$ grains per $\mathrm{m}^{2}$ ) of spelt wheat (which is the common practice in organic farms) will not result in a deterioration of the technological quality of this plant. The aim of this study was to compare the technological quality of grain and flour of two winter spelt cultivars grown under different agronomic conditions.

\section{Materials and methods}

A field study was carried out for two growing seasons 2013/2014 and 2014/2015 in the village of Czesławice where the Experimental Farm $\left(51^{\circ} 18^{\prime} 23^{\prime \prime} \mathrm{N}, 22^{\circ} 16^{\prime} 2^{\prime \prime}\right.$ E) belonging to the Lublin University of Life Sciences, Poland is located (Fig. 1). The experiment on growing spelt wheat was established on a loess-derived Luvisol, classified as good wheat soil complex and soil class II. The arable layer of the soil was characterized by high availability of phosphorus $\left(\mathrm{P}_{2} \mathrm{O}_{5}-175.1-178.2 \mathrm{mg} \mathrm{kg}^{-1}\right.$ soil $)$ and potassium $\left(\mathrm{K}_{2} \mathrm{O}-141.9\right.$ $-159.4 \mathrm{mg} \mathrm{kg}^{-1}$ soil) as well as medium availability of magnesium $\left(\mathrm{Mg}-79-85 \mathrm{mg} \mathrm{kg}^{-1}\right.$ soil), slightly acidic $\mathrm{pH}$ (in $1 \mathrm{M} \mathrm{KCl}-6.1-6.4$ ), and a humus content of $1.59-1.63 \%$. The 
experiment was conducted in three replicates. Two winter spelt wheat cultivars, the German cultivar 'Schwabenspelz' (Fig. 2) and the Polish cultivar 'Rokosz', were the object of this research.

The experiment included the following factors: I - seeding rate: 1) optimum -350 plants per $\mathrm{m}^{2}$; 2) increased - 500 plants per $\mathrm{m}^{2}$; II - crop protection: 1) pro-ecological: A - treatment without protection against pathogens (control treatment), B - harrowing in early spring at the beginning of the growing season; 2) chemical: $\mathrm{C}$ - application of the herbicides Sekator 125 OD (a.i. amidosulfuron, iodosulfuron, mefenpyr-diethyl) at a rate of $150 \mathrm{ml} \mathrm{ha} \mathrm{h}^{-1}$ and Attribut $70 \mathrm{WG}$ (a.i. propoxycarbazone-sodium) at a rate of $60 \mathrm{~g} \mathrm{ha}^{-1}$ at $\mathrm{BBCH} 22-24$ stages of spelt wheat; D - application of complete chemical protection the herbicides Sekator 125 OD (a.i. amidosulfuron, iodosulfuron, mefenpyr-diethyl) at a rate of $150 \mathrm{ml} \mathrm{ha}^{-1}$ and Attribut $70 \mathrm{WG}$ (a.i. propoxycarbazone-sodium) at a rate of $60 \mathrm{~g}$ $\mathrm{ha}^{-1}$ at $\mathrm{BBCH} 22-24$ stages of spelt wheat; the growth retardant Cerone 480 SL (a.i. ethephon) at $\mathrm{BBCH} 30-31$ stages at a rate of $0.751 \mathrm{ha}^{-1}$, the fungicide Wirtuoz $520 \mathrm{EC}$ (a.i. prochloraz, tebuconazole, proquinazid) at $\mathrm{BBCH} 24-25$ and 32-33 stages at a rate of $1.01 \mathrm{ha}^{-1}$ as well as the insecticide Decis 2,5 EC (a.i. deltamethrin) at BBCH 37-39 stages at an amount of $0.251 \mathrm{ha}^{-1}$.

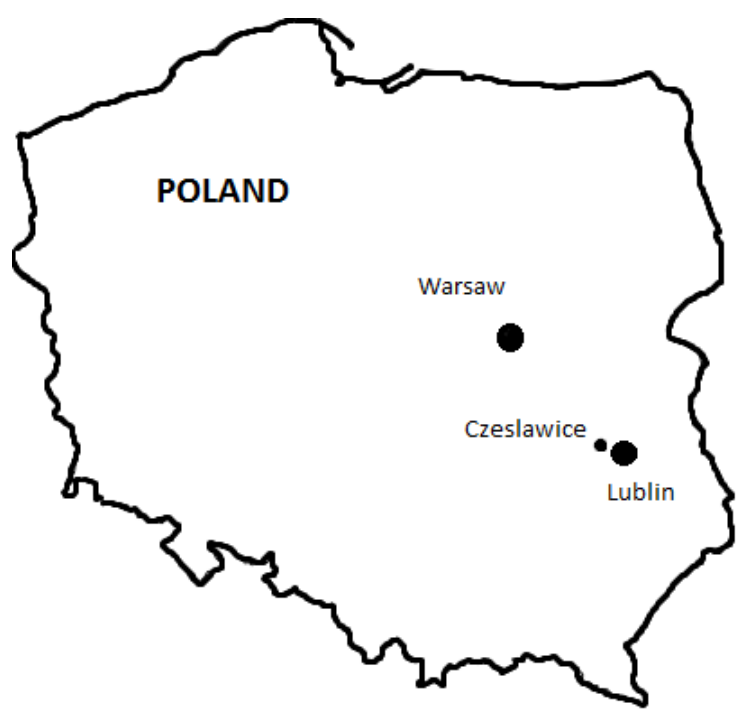

Figure 1. Localization of the study site

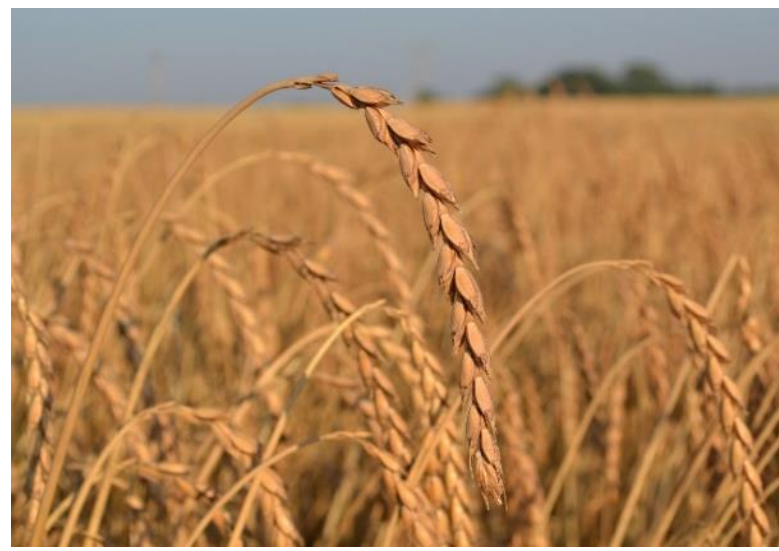

Figure 2. 'Schwabenspeltz' cultivar of spelt wheat 
Mineral fertilization was applied at the following rates: $\mathrm{N}-50 \mathrm{~kg} \mathrm{ha}^{-1}, \mathrm{P}_{2} \mathrm{O}_{5}-$ $60 \mathrm{~kg} \mathrm{ha}^{-1}$ and $\mathrm{K}_{2} \mathrm{O}-70 \mathrm{~kg} \mathrm{ha}^{-1}$. All phosphorus and potassium fertilizers and part of nitrogen fertilizers $(20 \mathrm{~kg} \mathrm{~N})$ were applied before sowing the spelt wheat. The remaining portion of nitrogen fertilizers was applied right after the beginning of the growing season. The sown and harvested plot area was $13.5 \mathrm{~m}^{2}(5.0 \times 2.7 \mathrm{~m})$. Winter wheat was the previous crop for spelt wheat. Tillage was typical for common wheat cultivation. The spelt wheat was sown on September 23, 2013 and September, 25, 2014 and it was harvested on August 12, 2014 and August 11, 2015.

Temperature range in both vegetation seasons of wheat spelt were similar. Mean temperature in season 2013/2014 was 8.7 and in season 2014/2015 was 0.1 higher (Table 1). Season 2013/2014 could be described as very wet as rainfall was by $281 \mathrm{~mm}$ higher than in season 2014/2015. In year 2014 the highest rainfall was in May, June and August. In year 2015 high rainfall was in May but August was very dry with only 5.9 $\mathrm{mm}$ of rain.

Table 1. Rainfall and air temperature in the growing season of spelt wheat, according to the Meteorological Station in Czestawice

\begin{tabular}{|c|c|c|c|c|c|c|c|c|c|c|c|c|c|}
\hline \multirow{2}{*}{ Years } & \multicolumn{12}{|c|}{ Months } & \multirow{2}{*}{ Sum/Mean } \\
\hline & IX & $\mathbf{X}$ & XI & XII & I & II & III & IV & $\mathbf{V}$ & VI & VII & VIII & \\
\hline \multicolumn{14}{|c|}{ Rainfalls (mm) } \\
\hline $2013 / 2014$ & 49.5 & 7.3 & 60.6 & 13.7 & 54.5 & 5.8 & 49.1 & 63.9 & 230.2 & 110.2 & 61.4 & 102.0 & 808.2 \\
\hline $2014 / 2015$ & 21.8 & 27.5 & 24.1 & 57.8 & 50.9 & 15.8 & 48.6 & 39.1 & 169.6 & 13.5 & 52.6 & 5.9 & 527.2 \\
\hline \multicolumn{14}{|c|}{ Temperature $\left({ }^{\circ} \mathrm{C}\right)$} \\
\hline $2013 / 2014$ & 11.3 & 9.5 & 4.9 & 1.7 & -2.9 & 0.3 & 4.9 & 8.9 & 13.0 & 15.2 & 19.6 & 18.3 & 8.7 \\
\hline $2014 / 2015$ & 14.0 & 9.7 & 4.6 & -0.1 & 1.0 & -1.1 & 2.8 & 6.5 & 11.5 & 16.1 & 19.0 & 21.9 & 8.8 \\
\hline
\end{tabular}

The following parameters were determined: 1000 grain weight (TGW) was determined according to PN-EN ISO 520:2011E. Clean material was placed in an automatic seed counter and $4 \times 250$ seeds were counted and weighed with an accuracy of $0.1 \mathrm{~g}$. Test weight was determined according to PN-EN ISO 7971-1:2010P. To analyse $\alpha$-amylase activity, SWD-SŻ type instrument (Sadkiewicz ${ }^{\circledR}$ Instruments, Bydgoszcz, Poland), was used, in which falling number was measured using the Hagberg-Perten method, according to PN-EN ISO 3093:2010E. The grain was milled in a laboratory 6-roller mill manufactured by the Research Institute of the Bakery Industry in Bydgoszcz. The milled flour was sieved in a laboratory sifter to obtain appropriate fractions for the individual assays, on sieves with proper mesh sizes $(265 \mu \mathrm{m}$ - for farinographic evaluation, $230 \mu \mathrm{m}$ - for determination of gluten quantity and quality, $150 \mu \mathrm{m}$ - for determination of sedimentation value). Determination of gluten content and weakening was performed according to PN-EN ISO 21415-2:2015-12E using the Gluten index system (Perten Instruments). Sedimentation value was determined according to PN-EN ISO 5529:2010E. This assay was performed on an apparatus consisting of a measurement panel and the Sadkiewicz vortex mixer (Sadkiewicz ${ }^{\circledR}$ Instruments, Bydgoszcz, Poland), SWD-89 model. Analysis of the farinographic properties of the dough was carried out on a farinograph (Brabender) using a 50 type head according to PN-EN ISO 5530-1:2015-01E. The following parameters were determined - flour water absorption, dough development time, dough stability, and degree of softening after $10 \mathrm{~min}$ and after $12 \mathrm{~min}$. 
The obtained results were statistically analysed by two-way analysis of variance using a completely randomized design. Statistical software FR-ANALWAR 5.2. was used for calculations. Confidence half-intervals were calculated by Tukey's test at a significance level of 0.05. Significant differences between these two groups of treatments: organic protection (treatments A and B) and chemical protection (treatments $\mathrm{C}$ and D), were evaluated based on the Scheffe test $(\alpha=0.05)$.

\section{Results}

Conducted research showed that in 2014 and 2015 experiment factors had significant influence on weight of 1000 grains of spelt wheat 'Rokosz' cultivar (Tables 2 and 3). In the first year of research the greatest TGW was described in cultivar with complete chemical protection (treatment D) but in 2015 in harrowing treatment (B) (Table 2). In both years increase in seeding rate had untoward influence on grain size 'Rokosz' cultivar (Table 3).

Table 2. The impact of crop protection on quality characteristic of the spelt wheat grain cultivar 'Rokosz' ( $A^{1}$ - control treatment, $B^{2}$ - harrowing in early spring at the beginning of the growing season, $C^{3}$ - application of the herbicides, $D^{4}$ - application of complete chemical protection, $n s^{*}-$ not significant at $p \leq 0.05$ )

\begin{tabular}{|c|c|c|c|c|c|c|c|c|}
\hline Years & $\begin{array}{c}\text { Experimental } \\
\text { factors }\end{array}$ & $\begin{array}{c}1000 \\
\text { grains } \\
\text { weight }(\mathrm{g})\end{array}$ & $\begin{array}{c}\text { Test weight } \\
\left(\mathbf{k g ~ h l}^{-1}\right)\end{array}$ & $\begin{array}{c}\text { Falling } \\
\text { number } \\
(\mathbf{s})\end{array}$ & $\begin{array}{c}\text { Gluten } \\
\text { content }(\%)\end{array}$ & $\begin{array}{c}\text { Gluten } \\
\text { weakening } \\
(\mathbf{m m})\end{array}$ & $\begin{array}{c}\text { Gluten } \\
\text { index }(\%)\end{array}$ & $\begin{array}{c}\text { Zeleny } \\
\text { sedimentation } \\
\text { value }(\mathbf{m l})\end{array}$ \\
\hline \multirow{4}{*}{2014} & $\mathrm{~A}^{1}$ & 28.41 & 72.20 & 304.00 & 31.93 & 0.75 & 51.00 & 17.65 \\
\hline & $\mathrm{B}^{2}$ & 27.90 & 71.80 & 325.75 & 31.57 & 0.50 & 51.25 & 17.67 \\
\hline & $\mathrm{C}^{3}$ & 28.41 & 70.50 & 248.00 & 33.37 & 0.25 & 41.25 & 17.43 \\
\hline & $\mathrm{D}^{4}$ & 30.69 & 74.60 & 324.75 & 28.60 & 0.50 & 59.00 & 17.20 \\
\hline \multicolumn{2}{|c|}{ LSD $_{0.05}$ (Tukey test) } & 0.55 & 0.57 & 20.33 & 1.28 & $\mathrm{~ns}^{*}$ & 9.02 & ns \\
\hline \multirow{4}{*}{2015} & $\mathrm{~A}^{1}$ & 34.91 & 80.45 & 365.25 & 18.47 & 2.62 & 46.50 & 15.37 \\
\hline & $\mathrm{B}^{2}$ & 37.77 & 80.55 & 372.25 & 19.13 & 4.88 & 49.00 & 15.60 \\
\hline & $C^{3}$ & 37.28 & 80.60 & 386.50 & 17.97 & 3.25 & 56.25 & 15.35 \\
\hline & $\mathrm{D}^{4}$ & 36.79 & 79.10 & 359.25 & 17.98 & 3.50 & 54.50 & 15.35 \\
\hline \multicolumn{2}{|c|}{ LSD $_{0.05}$ (Tukey test) } & 0.36 & 0.24 & 13.84 & 1.12 & 0.61 & 5.73 & ns \\
\hline \multirow{4}{*}{$\begin{array}{c}\text { Mean } \\
\text { for 2014- } \\
2015\end{array}$} & $\mathrm{~A}^{1}$ & 31.66 & 76.33 & 334.63 & 25.20 & 1.69 & 48.75 & 16.51 \\
\hline & $\mathrm{B}^{2}$ & 32.84 & 76.18 & 349.00 & 25.35 & 2.69 & 50.13 & 16.64 \\
\hline & $C^{3}$ & 32.85 & 75.55 & 317.25 & 25.67 & 1.75 & 48.75 & 16.39 \\
\hline & $\mathrm{D}^{4}$ & 33.74 & 76.85 & 342.00 & 23.29 & 2.00 & 56.75 & 16.28 \\
\hline \multicolumn{2}{|c|}{ LSD $_{0.05}$ (Tukey test) } & $\mathrm{ns}$ & ns & $\mathrm{ns}$ & 2.07 & $\mathrm{~ns}$ & $\mathrm{~ns}$ & $\mathrm{~ns}$ \\
\hline \multicolumn{9}{|c|}{ Comparison of the pro-ecological and chemical crop protection (mean for 2014-2015) } \\
\hline \multirow{2}{*}{\multicolumn{2}{|c|}{$\begin{array}{c}\text { pro-ecological }(\mathrm{A}, \mathrm{B}) \\
\text { chemical }(\mathrm{C}, \mathrm{D}) \\
\end{array}$}} & 32.25 & 76.25 & 341.81 & 25.28 & 2.19 & 49.44 & 16.58 \\
\hline & & 33.29 & 76.20 & 329.63 & 24.48 & 1.88 & 52.75 & 16.34 \\
\hline \multicolumn{2}{|c|}{ Scheffe's test $\mathrm{LSD}_{0.05}$} & ns & ns & ns & 1.82 & ns & ns & ns \\
\hline
\end{tabular}

In 'Schwabenspelz' cultivar, during the experiment (2014-2015), crop protection had significant influence on this parameter (Table 4). In 2014 the greatest TGW was described in treatment B but in 2015 in the treatment D. Increase in seeding rate in 2015 significantly decreased of TGW of 'Schwabenspelz' spelt wheat (Table 5). Mean results from 2014-2015 did not confirm that crop protection and seeding rate had significant influence on grain size of both studied cultivars and there was also no difference between pro-ecological and chemical crop protection (Tables 2 and 3,4,5). 
Table 3. The impact of seeding rate on quality characteristic of the spelt wheat grain cultivar 'Rokosz' ( $n s^{*}-$ not significant at $p \leq 0.05$ )

\begin{tabular}{|c|c|c|c|c|c|c|c|}
\hline $\begin{array}{l}\text { Experimental } \\
\text { factors }\end{array}$ & $\begin{array}{l}1000 \text { grains } \\
\text { weight }(\mathrm{g})\end{array}$ & $\begin{array}{l}\text { Test weight } \\
\quad\left(\mathrm{kg} \mathrm{hl}^{-1}\right)\end{array}$ & $\begin{array}{c}\text { Falling } \\
\text { number }(s)\end{array}$ & $\begin{array}{c}\text { Gluten } \\
\text { content }(\%)\end{array}$ & $\begin{array}{c}\begin{array}{c}\text { Gluten } \\
\text { weakening }\end{array} \\
(\mathbf{m m})\end{array}$ & $\begin{array}{c}\text { Gluten } \\
\text { index }(\%)\end{array}$ & $\begin{array}{c}\text { Zeleny } \\
\text { sedimentation value } \\
(\mathbf{m l})\end{array}$ \\
\hline \multicolumn{8}{|c|}{2014} \\
\hline optimum & 29.55 & 73.30 & 332.13 & 32.16 & 0.31 & 53.00 & 16.72 \\
\hline increased & 28.15 & 71.25 & 269.11 & 30.58 & 0.69 & 48.25 & 18.25 \\
\hline $\begin{array}{c}\text { LSD }_{0.05} \text { (Tukey } \\
\text { test) }\end{array}$ & 0.65 & 1.27 & $\mathrm{~ns}^{*}$ & ns & $\mathrm{ns}$ & $\mathrm{ns}$ & ns \\
\hline \multicolumn{8}{|c|}{2015} \\
\hline optimum & 37.62 & 80.25 & 378.25 & 18.79 & 3.50 & 50.12 & 15.48 \\
\hline increased & 35.75 & 80.10 & 363.38 & 17.99 & 3.62 & 53.00 & 15.36 \\
\hline $\begin{array}{c}\mathrm{LSD}_{0.05} \text { (Tukey } \\
\text { test) }\end{array}$ & 1.57 & ns & ns & ns & ns & ns & ns \\
\hline \multicolumn{8}{|c|}{ Mean for 2014-2015 } \\
\hline optimum & 33.59 & 76.78 & 355.19 & 25.48 & 1.91 & 51.56 & 16.10 \\
\hline increased & 31.95 & 75.68 & 316.25 & 24.28 & 2.16 & 50.63 & 16.81 \\
\hline $\begin{array}{c}\mathrm{LSD}_{0.05} \text { (Tukey } \\
\text { test) }\end{array}$ & ns & ns & $\mathrm{ns}$ & ns & ns & $\mathrm{ns}$ & $\mathrm{ns}$ \\
\hline
\end{tabular}

Table 4. The impact of crop protection on quality characteristic of the spelt wheat grain cultivar 'Schwabenspelz' ( $A^{1}$ - control treatment, $B^{2}$ - harrowing in early spring at the beginning of the growing season, $C^{3}$ - application of the herbicides, $D^{4}$ - application of complete chemical protection, $n s^{*}$ - not significant at $p \leq 0.05$ )

\begin{tabular}{|c|c|c|c|c|c|c|c|c|}
\hline Years & $\begin{array}{l}\text { Experimental } \\
\text { factors }\end{array}$ & $\begin{array}{c}1000 \\
\text { grains } \\
\text { weight }(\mathrm{g})\end{array}$ & $\begin{array}{l}\text { Test weight } \\
\quad\left(\mathrm{kg} \mathrm{hl}^{-1}\right)\end{array}$ & $\begin{array}{c}\text { Falling } \\
\text { number }(s)\end{array}$ & $\begin{array}{c}\text { Gluten } \\
\text { content }(\%)\end{array}$ & $\begin{array}{c}\text { Gluten } \\
\text { weakening } \\
(\mathrm{mm})\end{array}$ & $\begin{array}{c}\text { Gluten } \\
\text { index }(\%)\end{array}$ & $\begin{array}{c}\text { Zeleny } \\
\text { sedimentation } \\
\text { value }(\mathbf{m l})\end{array}$ \\
\hline \multirow{4}{*}{2014} & $\mathrm{~A}^{1}$ & 36.87 & 66.77 & 73.50 & 43.55 & 4.13 & 38.00 & 17.20 \\
\hline & $\mathrm{B}^{2}$ & 43.01 & 69.85 & 90.75 & 40.08 & 5.00 & 30.25 & 16.72 \\
\hline & $\mathrm{C}^{3}$ & 36.84 & 68.45 & 98.25 & 43.30 & 5.50 & 41.50 & 17.20 \\
\hline & $\mathrm{D}^{4}$ & 36.20 & 70.15 & 126.75 & 39.47 & 3.75 & 31.75 & 13.90 \\
\hline \multicolumn{2}{|c|}{ LSD $_{0.05}$ (Tukey test) } & 0.61 & 0.56 & 6.77 & $\mathrm{~ns}^{*}$ & 1.40 & ns & 1.66 \\
\hline \multirow{4}{*}{2015} & $\mathrm{~A}^{1}$ & 37.77 & 71.40 & 330.25 & 31.18 & 9.25 & 36.75 & 16.32 \\
\hline & $\mathrm{B}^{2}$ & 35.30 & 70.05 & 341.00 & 36.22 & 11.12 & 38.00 & 15.83 \\
\hline & $\mathrm{C}^{3}$ & 37.71 & 71.25 & 306.00 & 31.20 & 10.88 & 40.00 & 17.28 \\
\hline & $\mathrm{D}^{4}$ & 38.54 & 72.05 & 311.00 & 30.05 & 9.12 & 37.00 & 16.77 \\
\hline \multicolumn{2}{|c|}{ LSD $_{0.05}$ (Tukey test) } & 0.79 & 0.27 & 21.57 & 0.85 & 2.31 & 2.09 & 1.10 \\
\hline \multirow{4}{*}{$\begin{array}{c}\text { Mean } \\
\text { for } 2014- \\
2015\end{array}$} & $\mathrm{~A}^{1}$ & 37.32 & 69.09 & 201.88 & 37.37 & 6.69 & 37.38 & 16.76 \\
\hline & $\mathrm{B}^{2}$ & 39.16 & 69.95 & 215.88 & 38.15 & 8.06 & 34.13 & 16.28 \\
\hline & $\mathrm{C}^{3}$ & 37.28 & 69.85 & 202.13 & 37.25 & 8.19 & 40.75 & 17.24 \\
\hline & $\mathrm{D}^{4}$ & 37.37 & 71.10 & 218.88 & 34.76 & 6.44 & 34.38 & 15.34 \\
\hline \multicolumn{2}{|c|}{ LSD $_{0.05}$ (Tukey test) } & ns & ns & ns & ns & ns & 1.68 & ns \\
\hline \multicolumn{9}{|c|}{ Comparison of the pro-ecological and chemical crop protection (mean for 204-2015) } \\
\hline \multirow{2}{*}{\multicolumn{2}{|c|}{$\begin{array}{c}\text { pro-ecological }(\mathrm{A}, \mathrm{B}) \\
\text { chemical }(\mathrm{C}, \mathrm{D})\end{array}$}} & 38.24 & 69.52 & 208.88 & 37.76 & 7.38 & 35.76 & 16.52 \\
\hline & & 37.33 & 70.48 & 210.51 & 36.01 & 7.32 & 37.57 & 16.29 \\
\hline \multicolumn{2}{|c|}{ Scheffe's test LSD 0.05} & ns & ns & ns & ns & ns & ns & ns \\
\hline
\end{tabular}


Table 5. The impact of seeding rate on quality characteristic of the spelt wheat grain cultivar 'Schwabenspelz' ( $n s^{*}$ - not significant at $p \leq 0.05$ )

\begin{tabular}{|c|c|c|c|c|c|c|c|}
\hline $\begin{array}{c}\text { Experimental } \\
\text { factors }\end{array}$ & $\begin{array}{l}1000 \text { grains } \\
\text { weight }(\mathrm{g})\end{array}$ & $\begin{array}{l}\text { Test weight } \\
\quad\left(\mathrm{kg} \mathrm{hl}^{-1}\right)\end{array}$ & $\begin{array}{c}\text { Falling } \\
\text { number (s) }\end{array}$ & $\begin{array}{c}\text { Gluten } \\
\text { content }(\%)\end{array}$ & $\begin{array}{c}\begin{array}{c}\text { Gluten } \\
\text { weakening } \\
(\mathbf{m m})\end{array} \\
\end{array}$ & $\begin{array}{c}\text { Gluten } \\
\text { index }(\%)\end{array}$ & $\begin{array}{c}\text { Zeleny } \\
\text { sedimentation value } \\
(\mathbf{m l})\end{array}$ \\
\hline \multicolumn{8}{|c|}{2014} \\
\hline optimum & 38.86 & 68.69 & 84.88 & 38.42 & 4,25 & 35.00 & 16.50 \\
\hline increased & 37.60 & 68.93 & 109.75 & 44.78 & 4.94 & 35.75 & 16.01 \\
\hline $\begin{array}{c}\text { LSD }_{0.05} \text { (Tukey } \\
\text { test) } \\
\end{array}$ & $\mathrm{ns}^{*}$ & $\mathrm{~ns}$ & 11.12 & $\mathrm{~ns}$ & ns & ns & 0.16 \\
\hline \multicolumn{8}{|c|}{2015} \\
\hline optimum & 39.52 & 70.90 & 306.50 & 31.76 & 10.50 & 37.75 & 16.78 \\
\hline increased & 35.14 & 71.48 & 337.62 & 32.56 & 9.69 & 38.12 & 16.32 \\
\hline $\begin{array}{c}\mathrm{LSD}_{0.05} \text { (Tukey } \\
\text { test) }\end{array}$ & 0.79 & 0.32 & 30.18 & $\mathrm{~ns}$ & $\mathrm{~ns}$ & $\mathrm{~ns}$ & $\mathrm{~ns}$ \\
\hline \multicolumn{8}{|c|}{ Mean for 2014-2015 } \\
\hline optimum & 39.19 & 69.80 & 195.69 & 35.09 & 7.38 & 36.38 & 16.64 \\
\hline increased & 36.37 & 70.21 & 223.69 & 38.67 & 7.32 & 36.94 & 16.17 \\
\hline $\begin{array}{c}\mathrm{LSD}_{0.05} \text { (Tukey } \\
\text { test) } \\
\end{array}$ & ns & $\mathrm{ns}$ & ns & $\mathrm{ns}$ & ns & $\mathrm{ns}$ & $\mathrm{ns}$ \\
\hline
\end{tabular}

In the research years methods of crop protection had significant influence on test weight 'Rokosz' and 'Schwabenspelz' cultivars (Tables 2 and 4). In 2014 and 2015, in both cultivars, the greatest test weight was amongst grains from treatment with complete chemical crop protection, furthermore in 'Schwabenspelz' cultivar test weight in 2014 did not vary much between treatments B and D. In the first year of research increase in seeding rate, from 350 to 500 grains per $\mathrm{m}^{2}$, significantly decreased test weight of 'Rokosz' and in 2015 increased test weight of 'Schwabenspelz' cultivar (Tables 3 and 5). Mean result from research years did not confirm statistically significant relation between experiment factors and test weight.

In both research years crop protection had significant influence on falling number (Tables 2 and 3,4,5). In 2014 'Rokosz' cultivar shown the greatest falling number in treatment B and D (Table 2). In 2015 the greatest falling number was amongst treatment where herbicide was used (treatment $\mathrm{C}$ ). In the first year of the study, which was characterized by o lot of rainfall (Table 1), in 'Schwabenspelz' cultivar, the falling number was very low. The greatest falling number (126 s) was found in the treatment D (Table 4). In 2015, positive influence on falling number of grain had pro-ecological crop protection (treatments A and B) of 'Schwabenspelz' spelt wheat (Table 4). Seeding rate significantly modified the falling number in the 'Schwabenspelz' cultivar only. In each year of the study the increase in sowing rate adversely affected this feature (Table 5). Mean result from research years, as in the case of the feature discussed earlier, showed no significant influence of experiment factors on falling number of spelt wheat grains.

Crop protection methods caused significant differences in the amount of gluten in 'Rokosz' grain (Table 2). In the first year of research, the greatest gluten content in grains from treatment B was found, while in 2015 from control (A) and mechanical weed management (B) treatments. Mean from 2014-2015, the gluten content in the treatment with complete chemical protection was significantly lower than in the treatment where only the herbicide was applied (C) and in the treatment with harrowing 
(B), whereas it did not differ significantly with the control treatment. It was statistically proven that pro-ecological crop management affected more favourably the trait described compared to chemical crop protection (Table 2). In the second year of study, in 'Schwabenspelz' cultivar significantly influence of crop protection on this feature was observed (Table 4). The highest content of gluten was in grain from the harrowing treatment (B). With regards to this cultivar, despite no significant differences, proecological technologies also positively influenced grain gluten content (Table 4). In the case of the studied cultivars, the seedling rate did not significantly modify this feature (Tables 3 and 5).

In the years of research, the crop protection methods significantly differentiated the gluten weakening in grain of both spelt wheat cultivars (Tables 2 and 4). In 2015, in 'Rokosz' cultivar the highest gluten weakening was observed in the conditions where only herbicide was used (C), and the smallest in the control treatment (A) (Table 2). In both years of research in the grain of 'Schwabenspelz' cultivar harvested from the complete chemical protection treatment (D) was found the smallest gluten weakening (Table 4). In 2014, the highest value of discussed parameter in grain was recorded in the treatment $\mathrm{C}$, while in the second year of research (2015) in variant B (Table 4). Mean result from research years did not confirm statistically significant influence of crop protection on gluten weakening in the grain of both spelt wheat cultivars.

In the 2014 and 2015, gluten index of grain of studied cultivars varied significantly (Tables 2 and 4). In 2014, in the 'Rokosz' cultivar, the gluten index in the variant with complete chemical protection (treatment D) was significantly higher than in treatment $\mathrm{C}$, where only the herbicide was used (Table 2). In 2015, the value of the discussed parameter was different, as it was the highest in the treatments $C$ and $D$, while the lowest gluten index was shown in the grain from the control treatment (A). In 'Schwabenspelz' cultivar, in the second year of research (2015) the value of the gluten index varied significantly (Table 4). The highest value of this indicator was obtained in the treatment $\mathrm{C}$, where only the herbicide was used, and significantly lower in the treatment A and D. Mean results from 2014-2015 showed that the use of only herbicide (treatment C) in the crop protection of spelt wheat of the 'Schwabenspelz' cultivar significantly affects increase in the gluten index in comparison to other crop protection methods. In both spelt wheat cultivars the statistical analysis did not confirm the effect of seeding rate on gluten weakening and the gluten index (Tables 3 and 5). In the case of both cultivars, the values of gluten index were below normal in all treatments of experiment.

In 2014, in 'Schwabenspelz' cultivar significant influence of the crop protection on the value of the Zeleny sedimentation value was demonstrated (Table 4). In the treatment with complete chemical crop protection (D) a significantly lower Zeleny sedimentation value was obtained compared to other treatments. In 2014, in 'Schwabenspelz' cultivar proved the effect of seeding rate on Zeleny sedimentation value. A negative effect on the value of this indicator had increased seeding rate (Table 5).

All the grain quality characteristics were statistically proven to significantly vary between the cultivars studied, except for the sedimentation value (Table 6). 'Schwabenspelz', compared to 'Rokosz', showed better parameters with regard to TGW, gluten content, and falling number. On the other hand, 'Rokosz' was characterized by a significantly higher test weight and more favourable parameters of gluten weakening and index than 'Schwabenspelz'. 
Table 6. Quality characteristic comparison of the spelt wheat grain cultivars 'Rokosz' and 'Schwabenspelz' (mean for 2014-2015) (ns* - not significant at $p \leq 0.05$ )

\begin{tabular}{c|ccccccc}
\hline Cultivar & $\begin{array}{c}\text { 1000 grains } \\
\text { weight }(\mathbf{g})\end{array}$ & $\begin{array}{c}\text { Test weight } \\
\left(\mathbf{k g ~ h l}^{-1}\right)\end{array}$ & $\begin{array}{c}\text { Falling } \\
\text { number }(\mathbf{s})\end{array}$ & $\begin{array}{c}\text { Gluten } \\
\text { content }(\boldsymbol{\%})\end{array}$ & $\begin{array}{c}\text { Gluten } \\
\text { weakening } \\
(\mathbf{m m})\end{array}$ & $\begin{array}{c}\text { Gluten } \\
\text { index (\%) }\end{array}$ & $\begin{array}{c}\text { Zeleny } \\
\text { sedimentation } \\
\text { value (ml) }\end{array}$ \\
\hline Rokosz & 32.77 & 76.23 & 335.72 & 24.76 & 2.03 & 51.09 & 16.45 \\
Schwabenspelz & 37.78 & 70.00 & 209.69 & 36.88 & 7.34 & 36.66 & 16.40 \\
Mean & 35.28 & 73.11 & 272.70 & 30.82 & 4.69 & 43.88 & 16.43 \\
\hline $\begin{array}{c}\text { LSD }_{0.05} \text { (Tukey } \\
\text { test) }\end{array}$ & 1.76 & 2.40 & 30.13 & 1.77 & 0.62 & 3.38 & $\mathrm{~ns}^{*}$ \\
\hline
\end{tabular}

All studied parameters of both cultivars except for the gluten index and Zeleny sedimentation value differ significantly depending on the growing season (Figure 3). 'Rokosz' cultivar was characterized by a significantly higher TGW (A), test weight (B), falling number (C) and gluten weakening (E) in 2015 compared to 2014. Only gluten content (D) was significantly higher in the first year of experiment. In 2014 'Schwabenspelz' cultivar was characterized by significantly higher 1000 grains weight (A) and gluten content (D) than in the next year. In 2015 test weight (B), falling number (C) and gluten weakening (E) were characterized by significantly higher values.

When analysing the quality characteristics of spelt flour obtained from 'Rokosz', it was revealed that crop protection method caused significant differences in flour water absorption (Table 7). In all experimental treatments, the evaluated cultivars exhibited flour water absorption below 53\% (Tables 7 and 8). For mean result from research years significantly the highest value of this trait was found in the mechanical weed management treatment (B), while it was significantly lower when complete chemical protection was applied (treatment D). In the second year of the experiment, a significant influence of the method of crop protectiom methods on degree of dough softening after 12 min was observed. Mechanical weed management (B) caused a significant increase in this parameter (121.75 min) compared to the control (A) and herbicide treatment (C). Crop protection methods did not significantly differentiate other analysed parameters of flour and dough. In both years of the experiment, a significant effect of the seeding rate of the Rokosz cultivar on the parameters of flour and dough was observed (Table 8). In 2014, this factor significantly differentiated only the dough development time, which was significantly longer when the optimal seeding rate was used (2.18 min). In 2015, the optimum seeding rate had a significant impact on the dough development time and dough stability, resulting in an increase of these parameters to respectively $2.18 \mathrm{~min}$ and $2.64 \mathrm{~min}$. The degree of dough softening after 10 and after $12 \mathrm{~min}$ significantly increased in the variant of increased seeding rate.

During the experiment, in 'Schwabenspelz' cultivar, a significant influence of crop protection methods on flour water absorption and dough stability was observed (Table 9). In the first year of research, the flour obtained from the grain from the control treatment (A - 55.78\%) was characterized by the highest water absorption, while in the second year of the experiment the flour obtained from harrowing treatment (B $50.73 \%$ ). In 2014, the dough made from grain harvested from the complete chemical protection treatment (D) was characterized by the highest stability, whereas in 2015 the highest value of this feature was found in the herbicide treatment $(\mathrm{C})$ and in the complete chemical protection treatment (D), which did not significantly differ. 


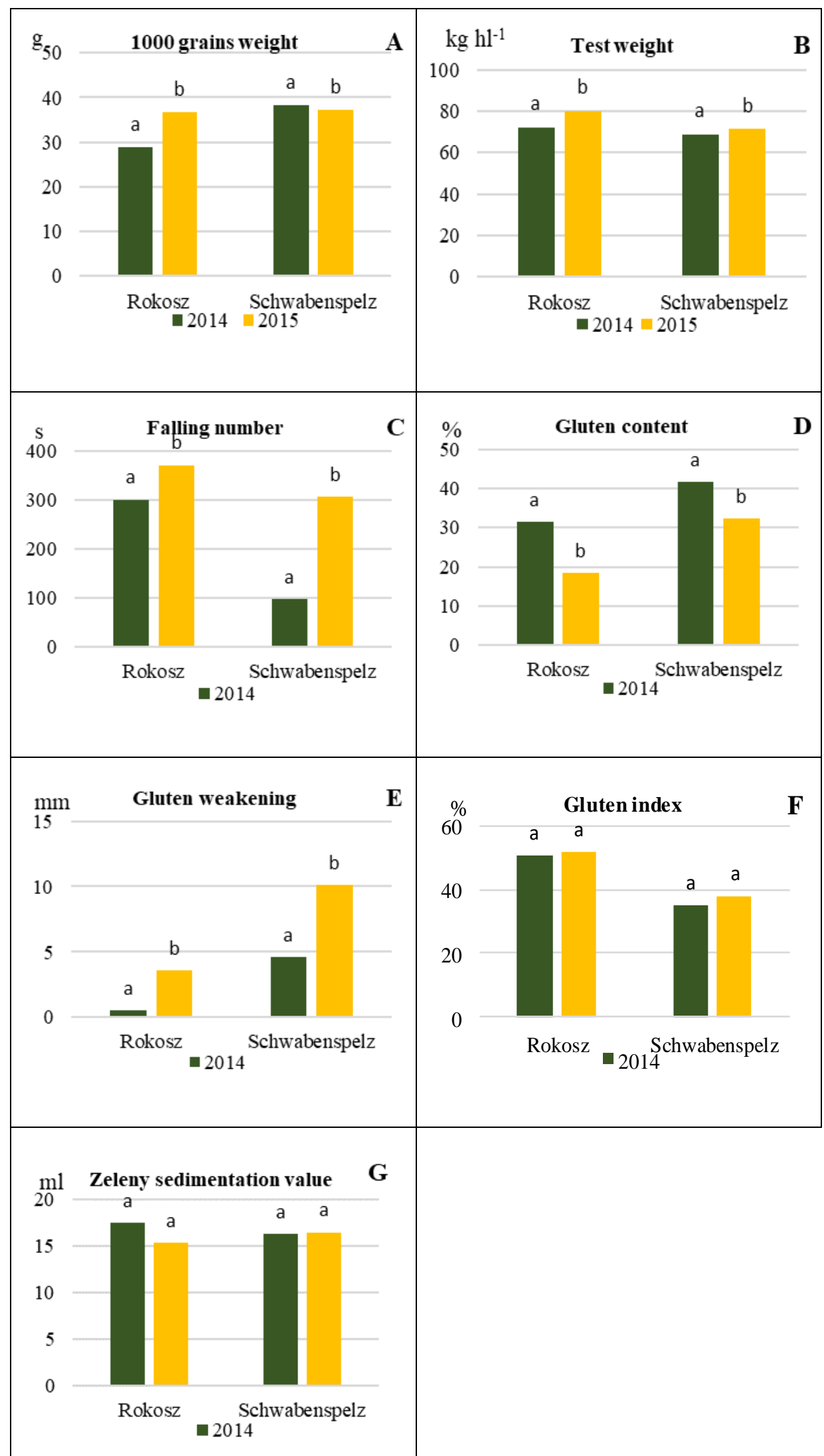

Figure 3. (A-G) Grain quality of the spelt wheat cultivars 'Rokosz' and 'Schwabenspelz' during the study years (independent on experimental factors) (different letters indicate significant difference at $p \leq 0.05$ ) 
Table 7. The impact of crop protection on farinographic features of flour and dough of the spelt wheat cultivar 'Rokosz' ( $A^{1}$ - control treatment, $B^{2}$ - harrowing in early spring at the beginning of the growing season, $C^{3}$ - application of the herbicides, $D^{4}$ - application of complete chemical protection, $F U^{5}$ - farinographic unit, $n s^{*}$ - not significant at $p \leq 0.05$ )

\begin{tabular}{|c|c|c|c|c|c|c|}
\hline Years & $\begin{array}{c}\text { Experimental } \\
\text { factors }\end{array}$ & \begin{tabular}{|c} 
Water absorption \\
of flour (\%)
\end{tabular} & $\begin{array}{c}\text { Dough } \\
\text { development } \\
\text { time (min) }\end{array}$ & $\begin{array}{c}\text { Dough } \\
\text { stability } \\
\text { (min) }\end{array}$ & $\begin{array}{c}\text { Degree of dough } \\
\text { softening after } 10 \\
\min \left(\mathrm{FU}^{5}\right)\end{array}$ & $\begin{array}{c}\text { Degree of dough } \\
\text { softening after } 12 \mathrm{~min} \\
\text { (FU) }\end{array}$ \\
\hline \multirow{4}{*}{2014} & $\mathrm{~A}^{1}$ & 55.03 & 1.90 & 2.80 & 113.50 & 139.50 \\
\hline & $\mathrm{B}^{2}$ & 55.55 & 2.00 & 3.12 & 99.25 & 117.75 \\
\hline & $\mathrm{C}^{3}$ & 56.10 & 2.18 & 2.50 & 108.00 & 133.25 \\
\hline & $\mathrm{D}^{4}$ & 54.00 & 1.97 & 2.75 & 92.00 & 123.25 \\
\hline \multicolumn{2}{|c|}{ LSD $_{0.05}$ (Tukey test) } & 0.59 & $\mathrm{~ns}^{*}$ & $\mathrm{~ns}$ & $\mathrm{~ns}$ & $\mathrm{~ns}$ \\
\hline \multirow{4}{*}{2015} & $\mathrm{~A}^{1}$ & 48.07 & 1.45 & 2.63 & 99.00 & 112.00 \\
\hline & $\mathrm{B}^{2}$ & 48.85 & 1.32 & 2.70 & 106.00 & 121.75 \\
\hline & $\mathrm{C}^{3}$ & 48.25 & 1.35 & 2.55 & 99.25 & 114.00 \\
\hline & $\mathrm{D}^{4}$ & 48.35 & 1.30 & 2.77 & 103.75 & 118.50 \\
\hline \multicolumn{2}{|c|}{ LSD $_{0.05}$ (Tukey test) } & 0.64 & $\mathrm{~ns}$ & $\mathrm{~ns}$ & $\mathrm{~ns}$ & 4.76 \\
\hline \multirow{4}{*}{$\begin{array}{l}\text { Mean } \\
\text { for } \\
2014- \\
2015\end{array}$} & $\mathrm{~A}^{1}$ & 51.55 & 1.68 & 2.72 & 106.25 & 125.75 \\
\hline & $\mathrm{B}^{2}$ & 52.20 & 1.66 & 2.91 & 102.63 & 119.75 \\
\hline & $\mathrm{C}^{3}$ & 52.18 & 1.77 & 2.53 & 103.63 & 123.63 \\
\hline & $\mathrm{D}^{4}$ & 51.18 & 1.64 & 2.76 & 97.88 & 120.88 \\
\hline \multicolumn{2}{|c|}{$\mathrm{LSD}_{0.05}$ (Tukey test) } & 0.98 & ns & $\mathrm{ns}$ & $\mathrm{ns}$ & ns \\
\hline \multicolumn{7}{|c|}{ Comparison of the pro-ecological and chemical crop protection (mean 2014-2015) } \\
\hline \multirow{2}{*}{\multicolumn{2}{|c|}{$\begin{array}{c}\text { pro-ecological }(\mathrm{A}, \mathrm{B}) \\
\text { chemical }(\mathrm{C}, \mathrm{D})\end{array}$}} & 51.88 & 1.67 & 2.82 & 104.44 & 122.75 \\
\hline & & 51.68 & 1.71 & 2.64 & 100.76 & 122.26 \\
\hline \multicolumn{2}{|c|}{$\begin{array}{l}\text { Scheffe's LSD } \\
(p=0,05)\end{array}$} & ns & ns & ns & ns & ns \\
\hline
\end{tabular}

Table 8. The impact of seeding rate on on farinographic features of flour and dough of the spelt wheat cultivar 'Rokosz' ( $F U^{l}-$ farinographic unit, $n s^{*}-$ not significant at $p \leq 0.05$ )

\begin{tabular}{|c|c|c|c|c|c|}
\hline Years $\begin{array}{c}\text { Experimental } \\
\text { factors }\end{array}$ & $\begin{array}{c}\text { Water } \\
\text { absorption of } \\
\text { flour }(\%)\end{array}$ & $\begin{array}{c}\text { Dough } \\
\text { development } \\
\text { time (min) }\end{array}$ & $\begin{array}{c}\text { Dough } \\
\text { stability } \\
\text { (min) }\end{array}$ & $\begin{array}{c}\text { Degree of dough } \\
\text { softening after } 10 \\
\text { min }\left(F U^{1}\right)\end{array}$ & $\begin{array}{c}\text { Degree of dough } \\
\text { softening after } 12 \mathrm{~min} \\
\text { (FU) }\end{array}$ \\
\hline \multicolumn{6}{|l|}{2014} \\
\hline optimum & 55.61 & 2.18 & 2.64 & 105.13 & 129.00 \\
\hline increased & 54.72 & 1.85 & 2.95 & 101.25 & 127.87 \\
\hline LSD $_{0.05}$ (Tukey test) & $\mathrm{ns}^{*}$ & 0.32 & $\mathrm{~ns}$ & $\mathrm{~ns}$ & $\mathrm{~ns}$ \\
\hline \multicolumn{6}{|l|}{2015} \\
\hline optimum & 48.79 & 1.46 & 3.21 & 93.12 & 109.50 \\
\hline increased & 47.98 & 1.25 & 2.11 & 110.88 & 123.6 \\
\hline LSD $_{0.05}$ (Tukey test) & $\mathrm{ns}$ & 0.16 & 0.63 & 3.18 & 4.76 \\
\hline \multicolumn{6}{|l|}{ Mean for 2014-2015 } \\
\hline optimum & 52.20 & 1.82 & 2.93 & 99.13 & 119.25 \\
\hline increased & 51.35 & 1.55 & 2.53 & 106.07 & 125.74 \\
\hline LSD $_{0.05}$ (Tukey test) & $\mathrm{ns}$ & ns & ns & ns & ns \\
\hline
\end{tabular}

Mean result from research years showed a significant effect of the studied factors only on dough stability. The highest value of this parameter was obtained in the complete crop protection (treatment D), which was significantly higher than in the pro- 
ecological crop protection variants (treatments A and B), and statistically the same as in the treatment C. Seeding rate did not significantly affect the tested parameters of flour and dough obtained from the grain of 'Schwabenspelz' cultivar (Table 10). In 2015, only significant differences in water absorption of flour were demonstrated. The flour from grain obtained from the increased seeding rate treatment was characterized by significantly higher water absorption compared to the optimum seeding rate treatment.

Table 9. The impact of crop protection on farinographic features of flour and dough of the spelt wheat cultivar 'Schwabenspelz' $\left(A^{1}\right.$ - control treatment, $B^{2}$ - harrowing in early spring at the beginning of the growing season, $C^{3}$-application of the herbicides, $D^{4}$-application of complete chemical protection, $F U^{5}-$ farinographic unit, $n s^{*}-$ not significant at $p \leq 0.05$ )

\begin{tabular}{|c|c|c|c|c|c|c|}
\hline Years & $\begin{array}{l}\text { Experimental } \\
\text { factors }\end{array}$ & $\begin{array}{c}\text { Water } \\
\text { absorption of } \\
\text { flour }(\%) \\
\end{array}$ & $\begin{array}{c}\text { Dough } \\
\text { development } \\
\text { time (min) } \\
\end{array}$ & $\begin{array}{l}\text { Dough } \\
\text { stability } \\
\text { (min) }\end{array}$ & $\begin{array}{c}\text { Degree of dough } \\
\text { softening after } 10 \\
\text { min }\left(\mathrm{FU}^{5}\right)\end{array}$ & $\begin{array}{c}\text { Degree of dough } \\
\text { softening after } 12 \mathrm{~min} \\
(\mathrm{FU})\end{array}$ \\
\hline \multirow{4}{*}{2014} & $\mathrm{~A}^{1}$ & 55.78 & 1.92 & 1.35 & 153.50 & 182.50 \\
\hline & $\mathrm{B}^{2}$ & 55.20 & 1.95 & 1.40 & 137.25 & 162.00 \\
\hline & $\mathrm{C}^{3}$ & 54.90 & 1.95 & 1.32 & 149.50 & 173.50 \\
\hline & $\mathrm{D}^{4}$ & 54.92 & 2.10 & 1.70 & 123.75 & 152.25 \\
\hline $\mathrm{LSD}_{0.05}$ & 5 (Tukey test) & 0.39 & $\mathrm{~ns}^{*}$ & 0.30 & $\mathrm{~ns}$ & $\mathrm{~ns}$ \\
\hline \multirow{4}{*}{2015} & $\mathrm{~A}^{1}$ & 49.45 & 1.85 & 1.83 & 132.25 & 149.00 \\
\hline & $\mathrm{B}^{2}$ & 50.73 & 1.80 & 1.77 & 125.25 & 149.75 \\
\hline & $\mathrm{C}^{3}$ & 49.57 & 1.85 & 2.08 & 110.75 & 126.25 \\
\hline & $\mathrm{D}^{4}$ & 48.95 & 1.70 & 2.22 & 105.00 & 120.75 \\
\hline \multicolumn{2}{|c|}{ LSD $_{0.05}$ (Tukey test) } & 0.97 & $\mathrm{~ns}$ & 0.23 & $\mathrm{~ns}$ & $\mathrm{~ns}$ \\
\hline \multirow{4}{*}{$\begin{array}{c}\text { Mean } \\
\text { for } 2014 \text { - } \\
2015\end{array}$} & $\mathrm{~A}^{1}$ & 52.62 & 1.89 & 1.59 & 142.88 & 165.75 \\
\hline & $\mathrm{B}^{2}$ & 52.97 & 1.88 & 1.59 & 131.25 & 155.88 \\
\hline & $\mathrm{C}^{3}$ & 52.24 & 1.90 & 1.70 & 130.13 & 149.88 \\
\hline & $\mathrm{D}^{4}$ & 51.94 & 1.90 & 1.96 & 114.38 & 136.50 \\
\hline \multicolumn{2}{|c|}{ LSD $_{0.05}$ (Tukey test) } & $\mathrm{ns}$ & $\mathrm{ns}$ & ns & 0.28 & $\mathrm{~ns}$ \\
\hline \multicolumn{7}{|c|}{ Comparison of the pro-ecological and chemical crop protection } \\
\hline \multirow{2}{*}{\multicolumn{2}{|c|}{$\begin{array}{c}\text { pro-ecological }(A, B) \\
\text { chemical }(C, D)\end{array}$}} & 52.80 & 1.89 & 1.59 & 137.07 & 160.82 \\
\hline & & 52.09 & 1.90 & 1.83 & 122.26 & 143.19 \\
\hline \multicolumn{2}{|c|}{$\begin{array}{l}\text { Scheffe's LSD } \\
\quad(p=0.05)\end{array}$} & $\mathrm{ns}$ & ns & $\mathrm{ns}$ & ns & $\mathrm{ns}$ \\
\hline
\end{tabular}

Table 10. The impact of seeding rate on on farinographic features of flour and dough of the spelt wheat cultivar 'Schwabenspelz' (FU $U^{l}$ - farinographic unit, $n s^{*}$ - not significant at $p \leq 0.05$ )

\begin{tabular}{|c|c|c|c|c|c|}
\hline Years $\begin{array}{c}\text { Experimental } \\
\text { factors }\end{array}$ & \begin{tabular}{|c} 
Water \\
absorption of \\
flour $(\%)$ \\
\end{tabular} & $\begin{array}{c}\text { Dough } \\
\text { development } \\
\text { time (min) } \\
\end{array}$ & $\begin{array}{c}\text { Dough } \\
\text { stability (min) }\end{array}$ & $\begin{array}{c}\text { Degree of dough } \\
\text { softening after } 10 \mathrm{~min} \\
\left(\mathrm{FU}^{1}\right)\end{array}$ & $\begin{array}{c}\text { Degree of dough } \\
\text { softening after } 12 \\
\text { min (FU) }\end{array}$ \\
\hline \multicolumn{6}{|c|}{ 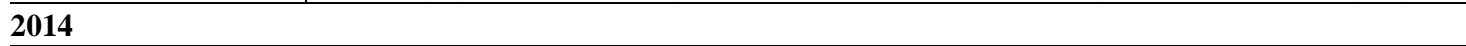 } \\
\hline optimum & 55.00 & 1.99 & 1.46 & 142.25 & 164.00 \\
\hline increased & 55.40 & 1.97 & 1.42 & 139.75 & 171.12 \\
\hline LSD $_{0.05}$ (Tukey test) & ns & ns & ns & ns & ns \\
\hline \multicolumn{6}{|l|}{2015} \\
\hline optimum & 49.50 & 1.78 & 1.95 & 120.37 & 139.75 \\
\hline increased & 49.85 & 1.82 & 2.00 & 116.25 & 133.12 \\
\hline LSD $_{0.05}$ (Tukey test) & 0.32 & ns & ns & $\mathrm{ns}$ & $\mathrm{ns}$ \\
\hline \multicolumn{6}{|l|}{ Mean for 2014-2015 } \\
\hline optimum & 52.25 & 1.89 & 1.71 & 131.31 & 151.88 \\
\hline increased & 52.63 & 1.90 & 1.71 & 128.00 & 152.12 \\
\hline LSD $_{0.05}$ (Tukey test) & ns & ns & ns & ns & ns \\
\hline
\end{tabular}


The performed variance analysis proved significant differences in dough stability and degree of softening between the cultivars evaluated (Table 11). 'Rokosz' was characterized by higher dough stability and a lower degree of softening after 10 and $12 \mathrm{~min}$. Despite that no significant differences were revealed, this cultivar showed lower flour water absorption and shorter dough development time compared to 'Schwabenspelz'.

Table 11. Comparison of the farinographic features of flour and dough of two cultivar of spelt wheat (mean for 2014-2015) ( $F U^{l}$ - farinographic unit, $n s^{*}$ - not significant at $\left.p \leq 0.05\right)$

\begin{tabular}{c|ccccc}
\hline Cultivar & $\begin{array}{c}\text { Water } \\
\text { absorption of } \\
\text { flour (\%) }\end{array}$ & $\begin{array}{c}\text { Dough } \\
\text { development time } \\
(\mathbf{m i n})\end{array}$ & $\begin{array}{c}\text { Dough stability } \\
(\mathbf{m i n})\end{array}$ & $\begin{array}{c}\text { Degree of dough } \\
\text { softening after 10 } \text { min } \\
\left(\text { FU }^{\mathbf{1}}\right)\end{array}$ & $\begin{array}{c}\text { Degree of dough } \\
\text { softening after 12 } \\
\text { min (FU) }\end{array}$ \\
\hline Rokosz & 51.78 & 1.68 & 2.73 & 102.59 & 122.50 \\
Schwabenspelz & 52.44 & 1.89 & 1.71 & 129.66 & 152.00 \\
Mean & 52.11 & 1.79 & 2.22 & 116.13 & 137.25 \\
\hline $\begin{array}{c}\text { LSD }_{0.05} \\
\text { (Tukey test) }\end{array}$ & $\mathrm{ns}^{*}$ & $\mathrm{~ns}$ & 0.31 & 10.84 & 12.85 \\
\hline
\end{tabular}

Water absorption of flour and dough development time of 'Rokosz' cultivar were significantly higher in 2014 compared to 2015 (Figure 4) (A-B). The other parameters of this cultivar were statistically the same (C-D). In the first year of experiment 'Schwabenspelz' cultivar was characterized significantly higher water absorption of flour and dough development time (A-B). Dough stability of this cultivar was significantly higher in 2015 compared to 2014 (C). Degree of dough softening after 10 min and after 12 min similarly to the 'Rokosz' cultivar, did not differ statistically.

The relationship between the quality characteristics and grain protein content (Table 12) differed for both cultivars studied.

Table 12. Straight correlation coefficients and simple regressions for the relationship between protein content $(x)$ and qualitative characteristics $(y)$ of grain, flour and dough of two cultivars of winter spelt $(n=16)\left(r_{\text {emp }}{ }^{l}-\right.$ Pearson correlation coefficient, $R^{2}-$ coefficient of determination, $\mathrm{FU}^{3}-$ farinographic unit, * - significance level $0.05, * *-0.01, * * *-$ $0.001)$

\begin{tabular}{ccccc}
\hline & \multicolumn{3}{c}{ Rokosz } \\
\hline Quality parametr & remp ${ }^{\mathbf{1}}$ & Significance & $\mathbf{R}^{\mathbf{2}}$ & Regression equation \\
\hline Gluten content (\%) & +0.81 & $* * *$ & 0.76 & $\mathrm{y}=-19.8+0.431 \mathrm{x}$ \\
Gluten weakening (mm) & -0.61 & $*$ & 0.66 & $\mathrm{y}=10.4-0.0813 \mathrm{x}$ \\
Zeleny sedimentation value (ml) & +0.53 & $*$ & 0.34 & $\mathrm{y}=10.8+0.0514 \mathrm{x}$ \\
Dough development time (min) & +0.71 & $* *$ & 0.82 & $\mathrm{y}=-1.06+0.0268 \mathrm{x}$ \\
\hline \multicolumn{5}{c}{ Schwabenspelz } \\
\hline Gluten content (\%) & +0.76 & $* * *$ & 0.56 & $\mathrm{y}=8.18+0.223 \mathrm{x}$ \\
Dough stability (min) & -0.65 & $* *$ & 0.38 & $\mathrm{y}=3.15-0.0112 \mathrm{x}$ \\
Degree of dough softening & +0.52 & $*$ & 0.42 & $\mathrm{y}=61.8+0.707 \mathrm{x}$ \\
after 12 min (FU $\left.{ }^{3}\right)$ & &
\end{tabular}

In 'Rokosz', with increasing protein content the amount of gluten, flour sedimentation, and dough development time increased, whereas gluten weakening decreased - which is evidence of its better quality. The values of determination 
coefficients $\left(\mathrm{R}^{2}\right)$ indicate that from $34 \%$ to $82 \%$ of the variability of these features is explained by the presented regression equations. 'Schwabenpeltz' was characterized by a positive relationship between protein content and gluten content $-56 \%$ of the variability was explained by the regression equation. As regards the other characteristics for which a statistically proven relationship was found (dough stability and weakening), gluten quality deteriorated with increasing protein content.

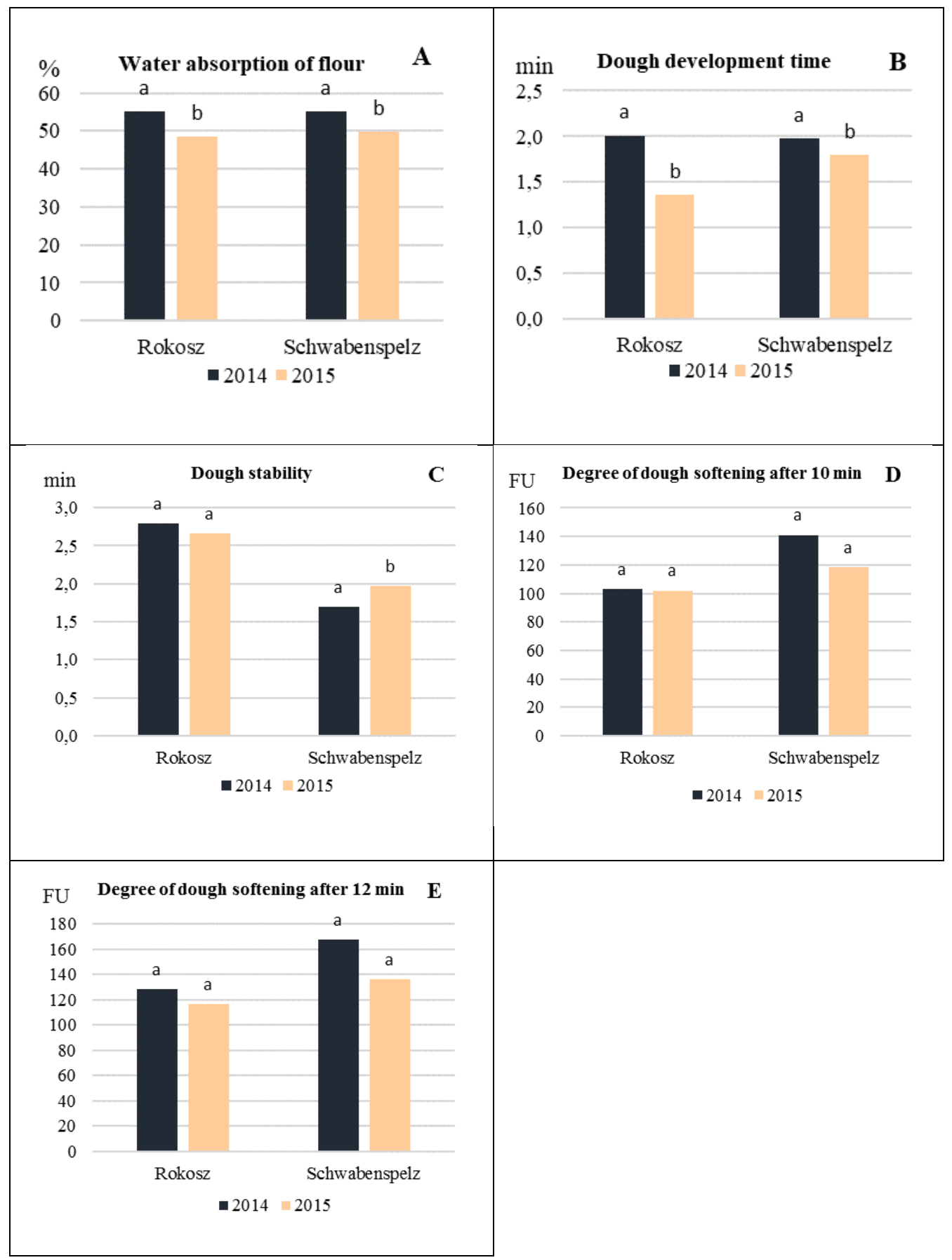

Figure 4. (A-E) Farinographic features of flour and dough of the spelt wheat cultivars 'Rokosz' and 'Schwabenspelz' during the study years (independent on experimental factors) (different letters indicate significant difference at $p \leq 0.05$ ) 


\section{Discussion}

Grain size is characterized by TGW. In the present study, TGW of cultivar 'Rokosz' was $32.77 \mathrm{~g}$, while for 'Schwabenspelz' it was $37.78 \mathrm{~g}$. The values of this trait were lower than those obtained by Capouchová (2001) (TGW = 52-54 g), Krawczyk et al. (2008b) $(\mathrm{TGW}=38.7-52.7 \mathrm{~g})$, Biel et al. (2016b) (TGW = 38.5-46.2 g), Andruszczak (2017) (39.3-50.7 g) and Petrenko et. al. (2018) (TGW = 56.5-56.7 g). As regards the test weight of 'Rokosz' grain, other authors reported similar values of the trait in question for different spelt wheat cultivars (Bastard, Oberlander, Burgdorf, Weisser, Schweizer, and Schwabenkorn) and lines (Makowska et al., 2008; Krawczyk et al., 2008b; Podolska et al., 2015; Biel et al., 2016b; Stankowski et al., 2016; Petrenko et al., 2018). Podolska et al. (2015) and Dorval et al. (2015) did not show seeding rate to have a significant effect on 1000 grain weight.

Falling number is a measure of $\alpha$-amylase activity (the higher the falling number, the lower the activity) (Rachon et al., 2011). The processing suitability of flour can be determined on this basis. In this study, the falling number for 'Rokosz' was $335.72 \mathrm{~s}$, whereas for 'Schwabenspelz' 209.69 s, which is evidence of the latter cultivar's higher amylolytic activity. Podolska et al. (2015) obtained slightly lower values for 'Rokosz', whereas the grain falling number of other cultivars and lines studied by Stankowski et al. (2016) ranged from 188 to 308 s, Biel et al. (2016b) - 134-295 s, Rachoń et al. (2016) - 334 s, Krawczyk et al. (2008b) - 259-287 s, and Petrenko et al. (2018) - 287303 s. Dorval et al. (2015) did not show seeding rate to have a significant effect on this parameter.

Gluten content and quality are an important indicator of baking quality of flour because they give proper elasticity to dough, and a spongy structure and springiness to bread. The average gluten content in 'Rokosz' spelt grain tested was $24.76 \%$ and weakening was $2.03 \mathrm{~mm}$, whereas in 'Schwabenspelz' grain these values were $36.88 \%$ and $7.34 \mathrm{~mm}$, respectively. Rachoń et al. (2013) found a significantly higher gluten content in spelt grain as affected by complete chemical protection $(42.5 \%)$ compared to the herbicide treatment (37.2\%). In other study, Rachon et al. (2016) showed an increased content of gluten $(44.9 \%)$ in wheat grain spelt under the influence of increased chemical protection intensity. In the study by Podolska et al. (2015), an increasing trend in the amount of gluten in 'Rokosz' grain was observed with a simultaneous increase in the seeding rate from 400 to 500 seeds per $1 \mathrm{~m}^{2}$. It was only when 600 seeds were sown that a significant decrease in this parameter occurred. These authors found much higher gluten weakening $(6.3-6.5 \mathrm{~mm})$ than in the present study, but seeding rate did not cause significant differences in this trait. Andruszczak (2018) did not find a significant effect of seeding rate on the content of gluten in the spring spelt grain.

Gluten index shows the quality of gluten and what grain and flour can be used for. Wheat flour used to make bakery products should be characterized by the gluten index at a level of $60-90 \%$. Determinations above and below this range indicate low baking quality (Stępniewska, 2015). This study showed the gluten index of 'Rokosz' (51.09\%) to be significantly higher than in 'Schwabenspelz' $(36.66 \%)$, but these values do not qualify the cultivars in question for material of high baking value. Podolska et al. (2015) found similar values of this indicator and seeding density did not result in significant differences in it.

The Zeleny sedimentation value was almost identical in both cultivars, averaging $16.43 \mathrm{ml}$, and the experimental factors did not cause variations in it. In the study by 
Stankowski et al. (2016), lower values of the investigated trait were observed (14.5 $\mathrm{ml})$ compared to the present study. On the other hand, Podolska et al. (2004), who proved a significant increase in values of the parameter studied with increasing intensity of chemical crop protection, found a higher sedimentation value. Likewise, Andruszczak (2017) demonstrated that under complete chemical crop protection spelt wheat was characterized by a significantly higher sedimentation index than under extensive cropping conditions. Krawczyk et al. (2008a) proved that the Zeleny sedimentation value of the studied cultivars and lines ranged 30-40 $\mathrm{ml}$. In the study on the cultivar 'Rokosz' conducted by Podolska et al. (2015), this value was at a level of 29-29.5 ml and it was not dependent on seeding rate. Andruszczak (2018) also did not find a significant effect of seeding rate on this parameter. Rachon et al. (2011) obtained similar values for line STH $3(28.2 \mathrm{ml})$, whereas for line 715 they were significantly lower $(20.7 \mathrm{ml})$.

According to Mikos and Podolska (2012), water absorption of spelt flour may reach even $65 \%$. 'Schwabenpeltz' was characterized by slightly higher flour water absorption compared to 'Rokosz', which is evidence of higher dough yield (Table 6). In the study by Podolska et al. (2015), in which seeding rate did not affect significantly this parameter, similar results were obtained $(53-53.3 \%)$. The spelt wheat lines evaluated by Rachoń et al. (2011) exhibited slightly higher water absorption (56.7-59\%). Cultivar 'Blauer Samtiger'evaluated in other study by Rachoń et al. (2016) are also characterized by a higher water absorption $(65.2 \%)$ than in the present study.

Dough stability is one of dough quality indicators and characterizes the resistance of flour to mixing (Rachoń et al., 2011). In 'Rokosz', this parameter was on average $2.73 \mathrm{~min}$ and significantly higher than in 'Schwabenspelz' (1.71 min) (Table 6). Information on higher values of the trait in question can be found in available scientific literature. The studies by Biel et al. (2016b), Rachoń et al. (2016) and Stanowski et al. (2016) demonstrated dough stability values at a level of 3.5, 5.8 and $4.48 \mathrm{~min}$, respectively. Podolska et al. (2015) did not show seeding rate to have a significant effect on this parameter, but a decreasing trend in these values could be observed with increasing plant density - from $3.2 \mathrm{~min}$ at a seeding rate of 400 seeds per $1 \mathrm{~m}^{2}$ up to 3.0 at a rate of 600 seeds. The higher the sum of the dough development time and dough stability, the longer the dough should be mixed. Therefore, spelt doughs require longer mixing than doughs made of common wheat flour (Krawczyk et al., 2008a).

The variance analysis proved significant differences in the degree of softening between the cultivars evaluated (Table 6). 'Schwabenspelz', compared to 'Rokosz', showed longer development time and a higher degree of softening. A higher value of the trait in question was obtained in the research conducted by Makowska et al. (2008) and Stankowski et al. (2016), which indicates that dough is characterized by a high degree of softening. Evaluating 5 spelt wheat cultivars, Makowska et al. (2008) demonstrated that their degree of softening was at a level of 107-142 FU, whereas in the study by Stankowski et al. (2016) it was on average 95.9 FU after 10 min and $122 \mathrm{FU}$ after 12 min. According to Wiwart et al. (2017) and Geisslitz et al. (2018), only some cultivars of spelt wheat have high breadmaking potential.

Similarly as in the present study, spelt wheat cultivars are characterized by high variation in chemical composition and grain technological quality also in the evaluation of other authors (Capouchová, 2001; Lacko-Bartošová et al., 2010; Świeca et al., 2014; Andruszczak, 2017). Weather conditions also have a great impact on grain quality of this species since they additionally increase intervarietal variation (Lacko-Bartošová et 
al., 2010; Wojtkowiak and Stępień, 2015). According to Pruska-Kędzior et al. (2008), in technological terms spelt wheat can be considered among the most valuable cereals. Most authors stress that it is a species that tolerates well extensive cropping without plant protection chemicals and is characterized by favourable grain and flour characteristics under organic farming conditions (Capouchová, 2001; Kwiatkowski et al., 2015). Nevertheless, Andruszczak (2017) demonstrated that application of complete chemical crop protection contributed to an improvement in some grain quality parameters.

\section{Conclusions}

The present study showed that crop protection method and seeding rate did not cause most of the quality characteristics of spelt grain and flour to significantly vary. Both the Polish cultivar 'Rokosz' and the German cultivar 'Schwabenspelz' exhibited similar technological quality of grain and flour under organic farming and chemical crop protection conditions. Therefore, both these cultivars can be recommended for cultivation in organic farms. In 'Rokosz', gluten content, Zeleny sedimentation value, and dough development time increased with increasing protein content, whereas gluten weakening decreased, which is evidence of better quality and baking value of this cultivar relative to 'Schwabenspelz'.

Currently, there is a continuous necessity to look for effective agrotechnical solutions that can be introduced to the organic farming. Due to the high nutritional value of spelt wheat and its usefulness for tillage under organic farming conditions, it is necessary to select cultivars of this species that best tolerate pro-ecological cultivation and which are characterized by the high technological values. It seems be necessary to undertake research into non-chemical methods of limiting the presence of pests, such as: sowing rate, mechanical crop protection, use of biostimulators, etc. in this crop.

\section{REFERENCES}

[1] Andruszczak, S. (2017): Reaction of winter spelt cultivars to reduced tillage system and chemical plant protection. - Zemdirbyste-Agriculture 104(1): 15-22.

[2] Andruszczak, S. (2018): Spelt wheat grain yield and nutritional value response to sowing rate and nitrogen fertilization. - The Journal of Animal \& Plant Sciences 28(5): 14761484.

[3] Babenko, L. M., Hospodarenko, H. M., Rozhkov, R. V., Pariy, Y. F., Pariy, M. F., Babenko, A. V., Kosakivska, I. V. (2018): Triticum spelta: Origin, biological characteristics and perspectives for use in breeding and agriculture. - Regulatory Mechanisms in Biosystems 9(2): 250-257.

[4] Benincasa, P., Galieni, A., Manetta, A. C., Pace, R., Guiducci, M., Pisante, M., Stagnari, F. (2015): Phenolic compounds in grains, sprouts and wheatgrass of hulled and nonhulled wheat species. - Journal of the Science of Food and Agriculture 95(9): 1795-1803.

[5] Biel, W., Jaroszewska, A., Stankowski, S., Sadkiewicz, J., Bośko, P. (2016a): Effects of genotype and weed control on the nutrient composition of Winter spelt (Triticum aestivum ssp. spelta) and common wheat (Triticum aestivum ssp. vulgare). - Acta Agricultura Scandinavica, Section B: Soil and Plant Science 66(1): 27-35.

[6] Biel, W., Stankowski, S., Sobolewska, M., Radkiewicz, J., Jaroszewska, A., Pużyński, S. (2016b): Effect of selected agronomic factors on the banking quality of winter spelt 
strains and cultivars (Triticum aestivum ssp. spelta) in comparison with common wheat (Triticum aestivum ssp. vulgare). - Romanian Agricultural Research 33: 1-8.

[7] Biel, W., Stankowski, S., Jaroszewska, A., Pużyński, S., Bośko, P. (2016c): The influence of selected agronomic factors on the chemical composition of spelt wheat (Triticum aestivum ssp. spelta) grain. - Journal of Integrative Agriculture 15(8): 1763-1769.

[8] Boukid, F., Folloni, S., Sforza, S., Vittadini, E., Prandi, B. (2018): Current trends in ancient grains-based foodstuffs: insights into nutritional aspects and technological applications. - Comprehensive Reviews In Food Science and Food Safety 17(1): 123136.

[9] Cacak-Pietrzak, G., Gondek, E., Jończyk, K. (2013): Comparison of internal structure and milling properties of spelt and bread wheat from ecological farming. - Zeszyty Problemowe Postępów Nauk Rolniczych 574: 3-10. (in Polish).

[10] Callejo, M. J., Vargas-Kostiuk, M. E., Rodr'1guez-Quijano, M. (2015): Selection, training and validation process of a sensory panel for bread analysis: influence of cultivar on the quality of breads made from common wheat and spelt wheat. - Journal of Cereal Science 61: 55-62.

[11] Capouchová, I. (2001): Technological quality of spelt (Triticum spelta L.) from ecological growing system. - Scientia Agriculturae Bohemica 32: 307-322.

[12] Dorval, I., Vanasse, A., Pageau, D., Dion, Y. (2015): Seeding rate and cultivar effects on yield, yield components and grain quality of spring spelt in eastern Canada. - Canadian Journal of Plant Science 95(5): 841-849.

[13] Escarnot, E., Jacquemin, J., Agneessens, R., Paquot, M. (2012): Comparative study of the content and profiles of macronutrients in spelt and wheat, a review. - Biotechnology, Agronomy, Society and Environment 16(2): 243-256.

[14] Geisslitz, S., Wieser, H., Scherf, K. A., Koehler, P. (2018): Gluten protein composition and aggregation properties as predictors for bread volume of common wheat, spelt, durum wheat, emmer and einkorn. - Journal of Cereal Science 83: 204-212.

[15] Kraska, P., Andruszczak, S., Kwiecińska-Poppe, E., Pałys, E. (2013): Effect of chemical crop protection on the content of some elements in grain of spelt wheat (Triticum aestivum ssp. spelta). - Journal of Elementology 18(1): 79-90.

[16] Krawczyk, P., Ceglińska, A., Izdebska, K. (2008a): Comparing rheological properties of dough and quality of bread made of spelt and common wheat flours. - ŻYWNOŚĆ. Nauka. Technologia. Jakość 4(59): 141-151. (in Polish).

[17] Krawczyk, P., Ceglińska, A., Kordialik, J. (2008b): Comparing the technological value of spelt grains to common wheat grains. - ŻYWNOŚĆ. Nauka. Technologia. Jakość 5(60): 43-51. (in Polish).

[18] Kwiatkowski, C., Haliniarz, M., Tomczyńska-Mleko, M., Mleko, S., KaweckaRadomska, M. (2015): The content of dietary fiber, amino acids, dihydroxyphenols and some macro- and micronutrients in grain of conventionally and organically grown common wheat, spelt wheat and proso millet. - Agricultural and Food Science 24(3): 195-205.

[19] Lacko-Bartošová, M. (2010): Nutritional quality and antioxidant capacity of Triticum spelta varieties. - Journal of Ecology Health 14(6): 290-294.

[20] Makowska, A., Obuchowski, W., Adler, A., Sulewska, H. (2008): Milling and breadmaking properties of some spelt varieties. - Fragmenta Agronomica 25(1): 228-239. (in Polish).

[21] Mikos, M., Podolska, G. (2012): Bread-making quality of old common bread (Triticum aestivum ssp. vulgare L.) and spelt (Triticum aestivum ssp. spelta L.) wheat cultivars. Journal of Food Agriculture and Environment 10(374): 221-224.

[22] Petrenko, V., Spychaj, R., Prysiazhniuk, O., Sheiko, T., Khudolii, L. (2018): Evaluation of three wheat species (Triticum aestivum L., T. spelta L., T. dicoccum (Schrank) Schuebl) commonly used in organic cropping systems, considering selected parameters of technological quality. - Romanian Agricultural Research 35: 255-264. 
[23] Podolska, G., Stypuła, G., Stankowski, S. (2004): Yield and grain quality of winter wheat depending on different plant protection intensity. - Annales Universitatis Mariae CurieSkłodowska Sectio E Agricultura 59(1): 269-276. (in Polish).

[24] Podolska, G., Rothkaehl, J., Górniak, W., Stępniewska, S. (2015): Effect of nitrogen levels and sowing density on the yield and banking quality of spelt wheat (Triticum aestivum ssp. spelta) cv. Rokosz. - Annales UMCS, s. E, Agricultura 70(1): 93-103. (in Polish).

[25] Pruska-Kędzior, A., Kędzior, Z., Klockiewicz-Kamińska, E. (2008): Comparison of viscoelastic properties of gluten from spelt and common wheat. - European Food Research and Technology 227: 199-207.

[26] Rachoń, L., Szumiło, G., Stankowski, S. (2011): Comparison of selected technological value indicators of common wheat (Triticum aestivum ssp. vulgare), durum wheat (Triticum durum) and spelt wheat (Triticum aestivum ssp. spelta). - Fragmenta Agronomica 28(4): 52-59. (in Polish).

[27] Rachon, L., Szumiło, G., Kurzydłowska, I. (2013): The effect of the production technology intensity on the grain quality of common, durum, spelt and einkorn wheat. Annales Universitatis Mariae Curie-Skłodowska Sectio E Agricultura 68(2): 60-68. (in Polish).

[28] Rachoń, L., Szumiło, G., Szafrańska, A., Kotyrba, D. (2016): Bread-making potential of selected spring wheat species depending on crop year and production technology intensity. - Zemdirbyste-Agriculture 103(4): 369-376.

[29] Rocznik Statystyczny Rolnictwa (2017): Statistical yearbook of agriculture. - Central Statistical Office, Warsaw (in Polish).

[30] Solarska, E., Marzec, M., Kuzdraliński, A., Muszyńska, M. (2012): The occurrence of mycotoxins in organic spelt products. - Journal of Plant Protection Research 52(2): 190195.

[31] Spychaj-Fabisiak, E., Barczak, B., Nowak, K., Jagielski, J. (2014): Amino acids composition of winter wheat grain protein depending on the seed certification class and on the cultivar. - Romanian Agricultural Research 31: 89-93.

[32] Stankowski, S., Pużyński, S., Sobolewska, M., Biel, W. (2016): Effect of weed control and swing rate on the baking quality of spelt in comparison with common wheat. Bulgarian Journal of Agricultural Science 22(4): 604-610.

[33] Stępniewska, S. (2015): Technological values of selected wheat cultivars. - Acta Agrophysica 22(1): 103-114. (in Polish).

[34] Świeca, M., Dziki, D., Gawlik-Dziki, U., Różyło, R., Andruszczak, S., Kraska, P., Kowalczyk, D., Pałys, E., Baraniak, B. (2014): Grinding and nutritional properties of six spelt (Triticum aestivum ssp. spelta L.) cultivars. - Cereal Chemistry 91(3): 247-254.

[35] Szumiło, G., Rachoń, L. (2015): Yields and quality of spring spelt wheat depending on sowing material. - Polish Journal of Agronomy 20: 9-14. (in Polish).

[36] Ugrenović, V., Bodroža Solarov, M., Pezo, L., Đisalov, J., Popović, V., Marić, B., Filipović, V. (2018): Analysis of spelt variability (Triticum spelta L.) grown in different conditions of Serbia by organic conditions. - Genetika 50(2): 635-646.

[37] Wiwart, M., Szafrańska, A., Wachowska, U., Suchowilska, E. (2017): Quality parameters and rheological dough properties of 15 spelt (Triticum spelta L.) varieties cultivated today. - Cereal Chemistry 94(6): 1037-1044.

[38] Wojtkowiak, K., Stępień, A. (2015): Nutritive value of spelt (Triticum aestivum spp. spelta L.) as influenced by the foliar application of copper, zinc and manganese. Zemdirbyste-Agriculture 102(4): 389-396.

[39] Zorovski, P., Popov, V., Georgieva, T. (2018): Growth and development of Triticum monococcum L., Triticum dicoccum Sch. and Triticum spelta L. in organic farming conditions. - Contemporary Agriculture, The Serbian Journal of Agricultural Sciences, 67(1): 45-50. 